\title{
Daily Behavioural Penderita Diabetes Mellitus Tipe 1 Sebagai Triggers Kekambuhan Ketoasidosis Diabetikum
}

\author{
Ana Fitria Nusantara, Achmad Kusyairi \\ Stikes Hafshawaty Pesantren Zainul Hasan, PIP Lt. 1, PZH Genggong, Pajarakan, \\ Gerojokan, Karangbong, Kec. Pajarakan, Probolinggo, Jawa Timur \\ Email: anafitriaachmad@gmail.com \\ $\begin{array}{ll}\text { Diterima tanggal } & : \text { 13 Juni } 2020 \\ \text { Direvisi tanggal } & : \text { 1 September } 2020 \\ \text { Dipublikasikan tanggal } & : \text { 10 Desember 2020 }\end{array}$
}

\begin{abstract}
Abstrak
Latar Belakang dan Tujuan: Diabetes melitus tipe 1 merupakan kelainan kronis dengan gangguan metabolisme karbohidrat, protein dan lemak yang disebabkan oleh kekurangan insulin absolut. Ketoasidosis diabetikum adalah komplikasi paling sering terjadi yang membutuhkan pengelolaan secara akurat untuk mencegah terjadinya kematian pada pasien dengan DM tipe 1. Tujuan pada penelitian ini adalah untuk mengeksplorasi perilaku harian penderita DM tipe 1 yang dapat menjadi pemicu serangan ulang ketoasidosis diabetikum.

Metode: Penelitian ini menggunakan desain kualitatif dengan pendekatan phenomenology. Pengumpulan data dengan cara wawancara tidak terstruktur dan observasi. selanjutnya dilakukan analisis tehnik Van Manen. Partisipan berjumlah 24 orang.

Hasil: Empat tema yang dihasilkan sebagai berikut: perilaku makan (jumlah, jenis, jam) sebelum terdiagnosa DM atau sebelum mengalami KAD, perilaku minum (jumlah, jenis, jam) sebelum terdiagnosa DM atau sebelum mengalami $\mathrm{KAD}$, perilaku diit di luar aturan yang dilakukan di luar rumah, stress fisik dan psikologis.

Simpulan dan Implikasi: Ketoasidosis diabetikum menjadi salah satu penyebab tingginya mortalitas pada usia anak. Oleh sebab itu penatalaksanaan pada penderita DM tipe 1 penting untuk dilakukan sehingga ketoasidosis tidak terjadi seperti memperhatikan perilaku makan, minum, diit, dan manajemen stress.
\end{abstract}

Kata Kunci: Daily Behavioural; Diabetes Mellitus; Kekambuhan; Ketoasidosis Diabetikum

\footnotetext{
Sitasi: Nusantara A F \& Kusyairi A. (2020). Daily behavioural penderita diabetes mellitus tipe 1 sebagai triggers kekambuhan ketoasidosis diabetikum. The Indonesian Journal of Health Science. 12(2), 101-109

Copyright: (C) 2020 Nusantara et al. This is an open-access article distributed under the terms of the Creative Commons Attribution-NonCommercial 4.0 International License, which permits unrestricted use, distribution, and reproduction in any medium, provided the original author and source are credited.

Diterbitkan Oleh: Universitas Muhammadiyah Jember

ISSN (Print): 2087-5053

ISSN (Online): 2476-9614
} 


\begin{abstract}
Introduction and Aim: Diabetes mellitus type $I$ is a chronic disorder with impaired carbohydrate, protein and fat metabolism that caused by absolute insulin deficiency. Diabetic ketoacidosis is the most common complication that requires accurate management to prevent death in children with type 1 diabetes. The purpose of this study is to explore the daily behavior of people with type 1 diabetes that can be a trigger for a repeat attack of diabetic ketoacidosis.

Methods: This study uses a qualitative design with a phenomenology approach. The data collection was using unstructured interviews and observations, than data was analyzed with Van Manen's technique. Number of participants is 24 people.

Results: The study obtained four themes as follows: eating behavior (amount, variety, time) before being diagnosed with DM or before having DKA, drinking behavior (amount, variety, time) before being diagnosed with DM or before having DKA, diit behavior outside the home rules, physical and psychological stress.

Conclusion: Diabetic ketoacidosis is one of that causes of high mortality in childhood. Therefore, patients management with type 1 diabetes is important to do, so that DKA does not occur, such as eating behavior, drinking behavior, diit, and stress management.
\end{abstract}

\title{
Keywords : Daily Behaviour; Diabetes Melilltus; Diabetic Ketoacidosis; Recurrence
}

\section{PENDAHULUAN}

Diabetes mellitus (DM) merupakan penyakit kronik yang mana angka kejadiannya mengalami peningkatan hampir di seluruh dunia. Tanda umum diabetes melitus adalah peningkatnya kadar gula darah yang disebabkan oleh gangguan metabolisme karbohidrat, protein dan lemak. Diabetes melitus yang sering terjadi pada usia anak adalah DM tipe 1. Pada penyakit tersebut anak mengalami defisiensi insulin absolut sebagai akibat dari rusaknya kelenjar pankreas karena proses autoimun (Pulungan, Annisa, dan Imada, 2019).

Masalah utama pada penderita DM tipe 1 di Indonesia adalah pengetahuan dan kesadaran masyarakat khususnya keluarga terdekat yang masih bisa dikategorikan kurang tentang diabetes melitus tipe 1 ini, akibatnya penderita mengalami keterlambatan diagnosis dan tatalaksana yang tepat.

Ketoasidosis diabetik (KAD) merupakan keadaan dekompensasi metabolik yang ditandai oleh hiperglikemia, asidosis dan ketosis. Keadaan tersebut terutama disebabkan oleh defisiensi insulin absolut atau relatif. KAD dan hipoglikemia merupakan komplikasi akut dari diabetes melitus yang paling sering terjadi akibat dari keadaan diuresis osmotik. Penderita KAD dapat mengalami dehidrasi berat dan bahkan sampai menyebabkan terjadinya syok.

KAD dapat menjadi tanda awal dari keadaan diabetes melitus tipe 1 dan juga sebagai dampak dari kebutuhan insulin yang meningkat pada penderita DM tipe 1 dengan infeksi, infark miokard dan adanya 
trauma (Wira dan Dewa, 2010). Pada beberapa kasus, DM tipe 1 terdiagnosa ketika penderita mengalami keadaan keatoasidosis. Hal ini terjadi karena diabetes melitus tidak diketahui sebelumnya sehingga penderita mengalami komplikasi ketoasidosis. Komplikasi terburuk pada kasus KAD adalah penderita dapat tidak tertolong. Akan tetapi hal tersebut dapat dihindari dengan cara cepat dan tepatnya diagnosis serta penatalaksanaan.

Lebih dari $90 \%$ diabetes melitus pada anak dan remaja adalah DM tipe 1. Tahun 2013 terdapat kurang lebih 65.000 anak berusia kurang dari 15 tahun menderita DM tipe 1 setiap tahunnya dan $13-80 \%$ terdiagnosis mengalami ketoasidosis diabetikum (WHO, 2013 dalam Ria dan Syazili, 2017). Sekitar 20\% dari penderita DM diketahui setelah terdiagnosa menderita KAD. Sedangkan penderita KAD yang sudah diketahui DM sebelumnya dapat dikenali adanya faktor pencetus sebesar $80 \%$, sedangkan $20 \%$ sisanya tidak diketahui faktor pencetusnya (Ria dan Syazili. 2017).

\section{METODE PENELITIAN}

Metode penelitian ini menggunakan metode qualitative dengan pendekatan phenomenology, yang bertujuan untuk memahami fenomena-fenomena yang terjadi dalam subyek penelitian, dimana peneliti akan mendeskripsikan hasil penelitian yang berupa kata-kata yang diperoleh selama mengadakan pengamatan dan wawancara dengan sejumlah informan.

Data

dikumpulkan

menggunakan metode wawancara tidak terstruktur pada 24 partisipan yang terdiri dari 12 orang tua dan 12 orang anak penderita DM Tipe I di
Kabupaten Probolinggo. Wawancara berlangsung selama 45-60 menit dan dilakukan bersamaan dengan kegiatan observasi. Jumlah partisipan dianggap telah memenuhi, karena informasi yang didapat mempunyai pola yang sama dan berulang kali sehingga sudah mencapai saturasi data. Hasil wawancara ditranskrip dan untuk mendapatkan tema, hasil wawancara dianalisis menggunakan metode Van Mannen.

\section{HASIL}

Tema 1: Perilaku makan (jumlah, jenis, jam) sebelum terdiagnosa DM atau kejadian KAD

\section{Hasil wawancara dengan} partisipan didapatkan bahwa kebiasan makan penderita sebelum terdiagnosa DM tipe 1 yakni makan dengan porsi yang tidak wajar (banyak) dengan frekuensi lebih dari 3 kali dalam satu hari. Pada umumnya adalah konsumsi karbohidrat berlebih dalam bentuk nasi dan olahan karbohidrat yang lain seperti bakso dan mi (instan ataupun olahan) dikonsumsi ketika di rumah maupun di luar rumah.

Selama terdiagnosa DM tipe 1 kebiasan makan pasien mengikuti aturan diit yang sudah diberikan akan tetapi hanya dilakukan dengan perhitungan perkiraan serta kebiasaan konsumsi makanan yang tidak terkontrol baik ketika di rumah maupun di luar rumah seperti di sekolah dan pada saat bermain.

"...kalau makan itu memang dia hobi sekali dengan porsi yang tidak wajar..."

“...oo kalau di sekolah dia biasanya beli makanan kayak mi itu..pentol cilot..gitu.." 
“...maksudnya nasi biasanya itu bu tapi porsinya porsi orang dewasa buanyak banget walaupun dia masih kecil..."

"...makannya banyak memang, tidak seperti anak seusianya,...oo lebih (dari 3 kali)"

"...senengannya itu beli bakso cilot itu..sama es krim, kalau gak dibelikan nesu (ngambek) dak mau bicara sama saya, namanya anak ya..saya turuti"

"...o lebih bu, bolak balik itu, bahkan malam sebelum tidur itu kalau gak dikasi makan dulu ya gak tidur-tidur"

\section{Tema 2: Perilaku minum (jumlah, jenis, jam) sebelum terdiagnosa DM atau kejadian KAD}

Berdasarkan hasil wawancara dengan partisipan didapatkan bahwa kebiasan minum pasien sebelum terdiagnosa DM tipe 1 yakni memiliki kebiasaan mengkonsumsi minuman manis seperti air gula dan minuman yang dijual bebas seperti jas jus, ale-ale, teh rio, es jus, es teh dan floridina sebagai minuman pokok serta kurang dalam mengkonsumsi air putih. Kebiasaan tersebut tidak serta merta berubah setelah terdiagnosa DM tipe 1 hanya saja tidak dilakukan di rumah dan jumlahnya berkurang. Akan tetapi beberapa partisipan pada momen tertentu seperti hari raya dapat mengkonsumsi minuman diatas lagi karena keinginan yang tidak dapat dikontrol.

“...dia suka ngeteh kayak minuman itu dah, ale-ale..."

“...es jus...es teh (mennjawab pertanyaan peneliti tentang perilaku minum sebelum sakit)..."
“ pokoknya kalau sudah kambuh berarti dia beli dak bilang saya dan bapaknya. kadang saya kasian ahirnya saya ijinkan juga.."

“...iya teh rio, ale-ale, anu juga air gula, dia ini sejak bayi minum air gula..."

"...Minumnya ale-ale itu, namanya anak-anak ya saya turuti waktu itu, paling sedikit sehari 4 botol, teh rio, jas jus, uuuh pokoknya..."

“...ini kalau dirumah gak mau manis-manis, maunya itu ale-ale itu lo bu..."

"...iya, dia ikut teman-teannya kalau di sekolah. Temannya beli dia ikut beli..."

"...kemarin itu yang terus kambuh itu dia beli es jas jus di sekolahnya, dibawa pulang diminum di rumah"

“...ini ikut mbahnya ke rumah saudara ceritanya..dia minum teh rio dak ketahuan sama mbahnya, setelah minum baru ketahuan, malemnya terus kambuh itu"

\section{Tema 3: Perilaku diit di luar aturan yang dilakukan di luar rumah}

Berdasarkan hasil wawancara dengan partisipan didapatkan bahwa pasien makan di luar rumah khususnya ketika di sekolah. Hal tersebut dilakukan oleh pasien meskipun di rumah sudah makan sesuai ketentuan diit. Keadaan tersebut tidak dapat di kontrol oleh orang tua maupun keluarga.

“...katanya temen temen cuma beli nasi tok gini, kan temen 2 nya bilang beli anu lek (beli nasi di sekolah) ( Kata temanya hanya beli nasi)..."

"...sangunya itu habis buat beli makanan, suka beli-beli juga kalau di 
sekolahnya...dikasi uang berapa gitu ya habis buat beli makanan di luar"

"...iya itu, itu kan ada jagung itu lo apa namanya, beli itu seneng dia (jasuke/jagung susu keju). Kalau beli eskrim yang besar itu tapi dikitdikit kalau makan..."

"...bukan (sosis), kayak mari mari (biskuit) iku seng coklat...beli 1, klau kurang nambah..."

$$
\text { "..bawa..saya bawakan }
$$

(dibawakan bekal dari rumah) tapi ya tetep kata temannya dia beli-beli makan juga di sekolah.."

“...Anu..dia ini pengenan anaknya, kalau temannya makan apa dia juga mau..saya berikan sedikit..gitu, kasian saya, anak-anak juga kan..."

\section{Tema 4: Stress Fisik dan Psikologis}

Berdasarkan hasil wawancara dengan partisipan didapatkan bahwa sebelum mengalami serangan KAD pasien mengalami kelelahan karena aktifitas fisik baik yang berkaitan dengan kepentingan sekolah ataupun tidak serta faktor psikologis. 100\% pasien adalah anak sekolah pada sekolah umum sehingga tidak ada perbedaan dengan anak yang tidak sakit.

“...anak saya ini kan aktif sekali ya, sampai capek saya nyuruh diem, padahal kan dia ini sakit ya..."

"...paginya itu kan ujian di sekolahnya...mikir paling..."

"...kecapean kayaknya, soalnya kalau habis sktifitas gitu pulang sekolah katanya capek itu biasanya sakit dia..."

"...main terus anaknya, kalau ndak saya paksa tidur siang dia main sampai sore. Kalau sudah capek gitu kambuh dia.." "..kecapean kemarin itu, saudaranya kan datang semua itu...jadi main terus. Sakit jadinya"

“....kalau kecapean kayak sekarang ini sebenarnya anu sekarang pondok romadhon tapi katanya pusing jadi ijin..."

"...anaknya kan lemes ya pak...ndak bisa capek. Kalau ulangan gitu belajar sampai malam, paginya sudah dak enak badan.."

“...stress, itu yang terakhir itu karena kelelahan dan telat makan, jadi langsung kumat..."

“...mau ujian..dia kan lama dak masuk sekolah waktu yang ke malang itu, berat mungkin jadinya.."

\section{PEMBAHASAN}

Berdasarkan pada hasil wawancara dan hasil analisis tema pada tujuan khusus ini, peneliti menemukan 4 tema, yaitu : Perilaku Makan (Jenis, Jumlah dan Jam) Sebelum Terdiagnosa DM dan atau Kejadian KAD, Perilaku Minum (Jumlah, Jenis, Jam) Sebelum Terdiagnosa DM dan atau Kejadian KAD, Perilaku Diet Di Luar Aturan Yang Dilakukan Di Luar Rumah (Penyebab Kekambuhan KAD/Komplikasi DM), Stress Fisik dan Psikologis. Hal ini ditunjukkan dengan beberapa pernyataan dan jawaban partisipan pada bab hasil.

Tema 1: Perilaku Makan (Jenis, Jumlah dan Jam) Sebelum Terdiagnosa DM dan atau Kejadian KAD.

Diet memainkan peranan penting dalam strategi terapi untuk menjaga penderita diabetes pada kontrol glikemik yang baik dan mencegah komplikasi mikro dan makrovaskuler. Namun pada realisasinya pengaturan nutrisi ini sangat sulit diterapkan mengingat 
adanya kebiasaan pola makan yang sulit dirubah dan berbeda beda. Salah satu kunci keberhasilan pengaturan makanan ialah asupan makanan dan pola makan yang sama sebelum maupun sesudah diagnosis (Rivellese et al, 2008).

Pengaturan makanan pada penderita DM tipe-1 bertujuan untuk mencapai kontrol metabolik yang baik tanpa mengabaikan kalori yang dibutuhkan untuk metabolisme basal, pertumbuhan, pubertas, maupun aktivitas sehari hari.

Partisipan mengkonsumsi makanan dengan bebas, satu-satunya yang dihindari adalah mengkonsumsi gula. Jenis makanan menentukan kecepatan naiknya kadar glukosa darah. Suatu makanan dalam menaikkan kadar gula darah disebut dengan indeks glikemik. Semakin cepat menaikkan kadar glukosa darah setelah makanan tersebut dikomsumsi, maka semakin tinggi indeks glikemik makanan tersebut (WDF, 2009).

Dalam menentuan jumlah makanan yang dikonsumsi partisipan tidak menggunakan alat ukur baku, tetapi menggunakan metode kira-kira dalam menentukan banyaknya makan pada anak. Begitu juga tentang waktu makan, orang tua lebih fleksibel terhadap waktu makan anak, disesuaikan dengan kondisi keluarga dan anak.

Komitmen orang tua dalam mengikuti aturan penatalaksanaan diet pada anak sangat dibutuhkan selaku keluarga terdekat yang merawat anak sehingga tujuan terapi dapat tercapai dan komplikasi tidak terjadi. Komitmen yang kuat diimbangi dengan kepatuhan dan pengetahuan yang baik dapat memberikan hasil yang maksimal. Diperkirakan hingga 50\% dari kasus
KAD dapat dicegah dengan cara pendidikan yang tepat untuk memfasilitasi identifikasi dan perawatan dini (Vitale et al, 2018).

\section{Tema 2: Perilaku Minum (Jenis, Jumlah dan Jam) Sebelum Terdiagnosa DM dan atau Kejadian KAD.}

Tidak berbeda dengan perilaku makan, penderita DM harus memperhatikan pola minum terutama jenis minuman yang dikonsumsi. Partisipan membiasakan anak untuk minum air putih di rumah, bahkan sebagian besar partisipan membawakan bekal air putih pada anak apabila ke sekolah atau kegiatan lain di luar rumah.

Dikarenakan usia penderita masih termasuk kategori anak yang cenderung belum bisa konsisten dalam mengikuti program terapi, seringkali anak meminta untuk minum minuman manis buatan seperti ale-ale, teh rio, dan sejenisnya. Dengan alasan kasian dan meredakan amarah anak akhirnya orang tua menuruti keinginan anak. Berdasarkan hal tersebut menumbuhkan kesadaran anak dan keluarga adalah prioritas. Pengalaman orang tua dalam mengelola terapi dan merawat penderita juga menjadi faktor penentu perilaku dan dalam menentukan sikap pada keinginan anak.

Riwayat anggota keluarga dengan penyakit diabetes mellitus sebelumnya dapat menyebabkan resiko KAD pada anak menjadi lebih rendah. Poin ini dapat menjadi salah satu cara pencegahan terjadinya KAD pada anak. Dengan pengalaman mengamati atau terlibat merawat anggota keluarga yang 
terdiagnosa DM sebelumnya, orang tua mengalami peningkatan kesadaran. Pengalaman diabetes mellitus sebelumnya meningkatkan kewaspadaan pada keluarga dan pada petugas kesehatan. oleh karena itu dapat disimpulkan bahwa kesadaran yang baik akan penyakit (diabetes mellitus) baik dalam keluarga ataupun masyarakat memiliki dampak yang sangat positif dalam hal diagnosis yang tepat dan pencegahan dini KAD (Cherubini et al, 2016).

\section{Tema 3: Perilaku Diet di Luar Aturan yang Dilakukan di Luar Rumah (Penyebab Kekambuhan KAD/Komplikasi DM)}

Partisipan mengkonsumsi makanan tidak memperhitungkan seberapa banyak yang dikonsumsi. Partisipan akan makan jika lapar dan ingin serta akan berhenti jika kenyang dan sudah tidak mau. Partisipan akan mengkonsumsi banyak makanan yang disukai walaupun itu tidak baik untuk tubuhnya dan akan menolak makanan yang tidak disukai tetapi dapat menunjang pengelolaan penyakitnya. Salah satu kunci keberhasilan pengaturan makanan ialah asupan makanan dan pola makan yang sama sebelum maupun sesudah diagnosis (Rivellese, 2008).

Prinsip makan pada penderita diabetes mellitus adalah mengatur konsumsi karbohidrat dengan tujuan gula darah terkontrol sehingga penderita berada pada keadaan sehat. Untuk mencapai tujuan tersebut tubuh memerlukan gizi yang cukup sehingga penderita dituntut untuk mampu mengelola makanan yang akan dikonsumsi. $100 \%$ orang tua dalam penelitian ini memastikan bahwa anak makan di rumah 3 kali dalam satu hari. Akan tetapi tidak dapat memastikan tentang perilaku makan anak di luar rumah. Hal ini terjadi karena orang tua tidak dapat mengontrol perilaku makan anak di luar rumah termasuk di sekolah. Hal ini memungkinkan partisipan untuk jatuh pada keadaan yang rentan dengan komplikasi.

\section{Tema 4: Stress Fisik dan Psikologis}

Penderita diabetes mellitus tipe 1 berada pada rentang usia anak yang masih aktif sekolah. Sebagian besar anak berada pada tahap sekolah dasar. Anak usia sekolah adalah anak dengan usia 6-12 tahun yang dapat mengekspresikan stimulus intelligence quotient atau melakukan tugas pembelajaran yang menuntut kemampuan intelektual atau kemampuan kognitif seperti: menghitung, membaca, dan menulis (Syamsu Y, 2011).

Anak usia sekolah dalam keadaan sehat akan lebih banyak bermain baik di dalam maupun di luar rumah bersama teman sebayanya dan melakukan banyak aktifitas sesuai dengan tumbuh kembangnya seperti berlari-lari, melompat serta sangat aktif untuk bergerak (Hardinsyah dan Supariasa, 2016). Tahap usia sekolah juga menuntut anak untuk banyak belajar sehingga tumbuh kembang kognitifnya juga sesuai. Akibat dari tingginya aktivitas fisik dan psikis yang dilakukan anak, jika tidak diimbangi dengan istirahat yang cukup dan menejemen diabetes yang tepat maka dapat menyebabkan terjadinya kelelahan fisik yang selanjutnya akan mempengaruhi kesehatan penderita sehingga 
menimbulkan komplikasi diabetik seperti ketoasidosis.

Terdapat beberapa faktor yang meningkatkan resiko terjadinya ketoasidosis pada penderita diabetes yaitu : perbedaan informasi tentang diabetes yang diterima, banyaknya informasi tentang keadaan penyakit yang diterima, lamanya menderita penyakit, informasi yang berlebihan tentang kondisi penyakit, keadaan geografis daerah tempat tinggal, kurangnya akses terhadap tenaga kesehatan spesialis, serta beban psikologis yang dialami oleh remaja yang dirawat oleh keluarga selain orang tua. (Chafe, et al. 2015). Anak dengan DM tipe 1 yang tidak tinggal atau tidak dirawat langsung oleh orang tua memiliki kecenderungan mengalami komplikasi berupa KAD (Usher-Smith Et al, 2011).

Dukungan dari masyarakat sekitar, informasi baru tentanga $\mathrm{KAD}$, telpon seluler, informasi yang tepat dan ringkas bagi pihak sekolah dan keluarga/wali serta set kelengkapan perawatan KAD untuk orang tua dapat membantu meningkarkan menejemen diabetes mellitus tipe 1 dan mencegah serangan KAD berulang. Selain itu ketidakpatuhan menejemen terapi insulin juga menjadi faktor penyebab terjadinya KAD (Chafe et al, 2015)

\section{SIMPULAN}

Berdasarkan hasil penelitian dapat disimpulkan bahwa perilaku harian yang dapat menyebabkan terjadinya komplikasi ketoasidosis diabetikum pada penderita diabetes melitis tipe 1 adalah perilaku makan (jumlah, jenis, jam) sebelum terdiagnosa DM atau kejadian KAD, perilaku minum jumlah, jenis, jam) sebelum terdiagnosa DM atau kejadian KAD, perilaku diit di luar aturan yang dilakukan di luar rumah, serta stres fisik dan psikologi.

\section{SARAN}

Sebagai bentuk pencegahan serangan KAD berulang dapat dilakukan dengan cara melakukan enam pilar penatalaksanaan diabetes mellitus, yaitu terapi insulin, diet, exercise, edukasi, pemantauan mandiri dan kontrol metabolik yang ditunjang dengan dukungan oleh keluarga terdekat dan petugas kesehatan.

\section{DAFTAR PUSTAKA}

Chafe, R., Albrechtsons, D., Hagerty, D., Newhook, L. A. (2015). Reducing episodes of diabetic ketoacidosis within a youth population: a focus group study with patients and families. BMC. BMC Res Notes. DOI 10.1186/s13104015-1358-7

Cherubini, V., Skrami, E., Ferrito, L., Zucchini, S., et al. (2016). High frequency of diabetic ketoacidosis at diagnosis of type 1 diabetes in Italian children: a nationwide longitudinal study, 2004-2013. Scientific Reports 6:38844 | DOI: $10.1038 /$ srep38844

Hardinsyah dan Supariasa, IDN. (2016). Ilmu Gizi Teori dan Aplikasi. Jakarta: EGC

Pulungan AB, Annisa D, dan Imada S. (2019). Diabetes Melitus Tipe-1 pada Anak : Situasi di Indonesia dan Tata Laksana. Sari Pediatri. Vol. 20, No. 6. 20(6):392-400

Ria Janita R dan Syazili Mustofa. (2017). Penatalaksanaan KAD dan DM tipe 1 pada Anak Usia 
15 Tahun. Jurnal Medula Unila Volume 7 Nomor 2

Rivellese, A. A., Boemi, M., Cavalot, F., Costagliola, L., De Feo, P., Miccoli, R., ... \& Zavaroni, I. (2008). Dietary habits in type II diabetes mellitus: how is adherence to dietary recommendations?. European journal of clinical nutrition, 62(5), 660-664.

Syamsu, Yusuf, LN. (2011). Psikologi perkembangan anak dan remaja. PT Remaja Rosdakaryam

Usher-Smith, J.A., Thompson, M.J., Sharp, S.J., Walter, F.M. (2011). Factors associated with the presence of diabetic ketoacidosis at diagnosis of diabetes in children and young adults: a systematic review. BMJ. doi: 10.1136/ bmj. d4092 Vitale, R. J., Card, C. E., Lichtman, J. H. (2018). An Effective Diabetic Ketoacidosis Prevention Intervention in Children With Type 1 Diabetes. Sage Open Nursing. Volume 4: 1-6

Wira, G., Dewa, Gede AB. (2010). Penatalaksanaan Ketoasidosis Diabetik (KAD). Jurnal Penyakit Dalam. Vol. 11, No. 2 World Diabetes Foundation. (2009). Konsensus nasional Pengelolaan Diabetes mellitus tipe 1. Badan penerbit ikatan dokter anak Indonesia. 978979-8421-38-9. 